\title{
KARAKTERISTIK POLITIK ISLAM: \\ Mencari Relevansi antara Doktrin dan Realitas Empirik
}

\author{
Abdurrahman Kasdi \\ STAIN Kudus \\ abdurrahman_ksd@yahoo.com
}

\begin{abstract}
Abstrak
Artikel ini mencoba mengkaji masalah relasi antara Islam dengan Negara. Hampir setiap muslim meyakini pentingnya prinsip-prinsip Islam dalam kehidupan politik. Namun, karena karakteristik Islam yang multi interpretatif, maka tidak pernah ada pandangan tunggal tentang bagaimana Islam dan politik harus berkorelasi dengan benar. Bahkan, sepanjang perjalanan sejarah intelektual dan praktek politik Islam, ada dua spektrum pemikiran yang berbeda tentang politik Islam. Keduanya mengakui pentingnya prinsip-prinsip Islam dalam setiap aspek kehidupan, namun keduanya memiliki interpretasi yang berbeda tentang ajaranajaran Islam dan relevansinya dalam kehidupan modern. Perbedaan tersebut bersumber pada bagaimana menafsirkan teks-teks agama yang berkaitan dengan hubungan agama (Islam) dan negara (politik).
\end{abstract}

\begin{abstract}
This article attempts to analyse the problem of the relationship between Islam and the state. Almost every Muslim believes the importance of the principles of Islam in political life. However, due to the multi interpretative characteristics of Islam, there will never be a single view of how Islam and politics should correlate correctly. In fact, throughout the course of intellectual history as well as political practice of Islam, there are two different views about the spectrum of political Islam. Although both views recognized the importance of the principles of Islam in every aspect of life, they have a different interpretation of the teachings of Islam and its relevance to the modern life. Such a difference emerges from the different interpretation of religious texts pertaining to the relationship between religion (Islam) and state (politics).
\end{abstract}

Kata Kunci: Politik Islam, Doktrin, Realitas Empirik. 


\section{A. Pendahuluan}

Agama Islam, merupakan agama yang paling mudah menerima instrumen ilmiah terkait realitas dunia. ${ }^{1}$ Premis ini alasan utamanya terletak pada ciri Islam yang paling menonjol, yaitu sifatnya yang hadir di mana-mana sebagai panduan moral yang benar bagi tindakan manusia. Pandangan ini telah mendorong sejumlah pemeluknya untuk meyakini bahwa Islam mencakup cara hidup yang total.

Implementasinya dinyatakan dalam Syari'ah (hukum Islam), bahkan sebagian kalangan Islam melangkah lebih jauh dari itu; mereka menekankan bahwa Islam adalah sebuah totalitas yang padu dan menawarkan solusi terhadap semua masalah kehidupan manusia. Tidak diragukan lagi, mereka percaya akan sifat Islam yang sempurna dan menyeluruh, sehingga menurut mereka, Islam meliputi tiga 'D' (din, agama; dunya, dunia; dan daulah, negara). Dalam konteks sekarang, dunia menyaksikan fenomena umat Islam yang ingin mendasarkan seluruh kerangka kehidupan politik, sosial, dan ekonomi pada ajaran Islam secara komprehensif.

Pandangan holistik terhadap Islam, sebagaimana diungkapkan di atas mempunyai beberapa implikasi. Salah satu di antaranya, pandangan itu telah mendorong lahirnya sebuah kecenderungan untuk memahami Islam dalam pengertiannya yang menyeluruh. Kecenderungan seperti ini akan dapat dikembangkan dalam konteks empirik manakala Islam dipahami secara kontekstual. Ini berarti bahwa Islam yang empirik dan aktual - karena berbagai perbedaan dalam konteks sosial, ekonomi dan politik - akan dipahami sesuai konteksnya.

\section{B. Tafsir Negara Islam}

Bersamaan dengan ramainya tuntutan aspirasi politik Islam di negara-negara yang mayoritas penduduknya Muslim, isu negara Islam semakin kuat bergulir di tengah kehidupan publik. Seakan-akan negara Islam dianggap sebagai formulasi ideal bagi kehidupan politik di masa sekarang ini. Sehingga, teoretisasi dan konseptualisasi ulang terhadap al-Qur'an dan hadits tentang negara

${ }^{1}$ Al-Qur'an mengajak para ilmuan untuk merenungi apa yang dikabarkan dalam ayat-ayat kauniyah dan menantang kebenarannya dengan teori ilmiah. 
Islam diperlukan lagi adanya interpretasi baru, mengingat konsep negara Islam tidak begitu jelas dalam wacana politik Islam, atau konseptualisasi negara Islam sesungguhnya sudah ketinggalam zaman. Kemungkinan-kemungkinan ini perlu ditelusuri lagi dalam doktrin Islam; al-Qur'an dan hadits untuk menemukan kejelasan teologis mengenai negara Islam.

Kemudian, seperti apakah konsep negara Islam yang selama ini dipahami oleh para pendukungnya? Menurut Javid Iqbal (1987), Negara Islam adalah negara Allah, negara yang memberlakukan Syari'at Islam, dan kedaulatan di tangan Tuhan (Allah Swt). Secara teoritis, negara Islam memiliki tiga komponen penting, yakni; (1) masyarakat muslim, (2) hukum Islam atau Syari'at Islam, dan (3) khalifah. Tiga komponen ini menjadi prasyarat berdirinya negara Islam yang sah.

Formulasi ini kemudian dijabarkan lebih lanjut oleh Hasan Turabi (1987), bahwa negara Islam memiliki landasan teologis yang kuat, yakni: (1) Negara Islam tunduk pada doktrin tauhid, yang meniscayakan religiusitasnya dan sebaliknya menolak sekularitas. (2) Negara Islam bukanlah negara yang dibatasi oleh wilayah teritorial (nasionalitas), karena kesetiaan utama hanya diberikan kepada Tuhan, setelah itu barulah diserahkan kepada masyarakat (umat). Karena itu, Islam tidak memperbolehkan adanya kesetiaan terbatas; etnis atau teritorial. (3) Negara Islam bukanlah suatu kesatuan yang berdaulat, karena ia tunduk kepada norma-norma Syari'at yang lebih tinggi, yang mewakili kehendak Tuhan. Bahkan, oleh Abu A'la al-Maududi (1967), negara Islam diletakkan pada prinsip utamanya pada pengakuan kedaulatan Tuhan sebagai sumber segala hukum. Maka, tidak seorang pun yang dapat menetapkan hukum, kecuali Allah Swt. sebagai pemilik kedaulatan tunggal. Al-Maududi dalam "al-Hukumah al-Islamiyah" menegaskan bahwa pemerintahan Islam atau negara Islam diambil dari kata "khalifah" dalam al-Qur'an, yang pada hakikatnya adalah khilafah Ilahiyah (khilafah Islamiah).

Gagasan ini dapat dilihat dari rumusan konstitusi versi Abu A'la al-Maududi yang terkenal dengan "Tuntutan Empat Butir" di Pakistan:(1) Sesungguhnya kedaulatan di Pakistan adalah di (tangan) Allah, dan oleh karenanya pemerintah (Pakistan) sebagai pelaksana 
kedaulatan itu tidak boleh melampaui batas yang ditentukan oleh pemilik kedaulatan (Allah). (2) Syari'at Islam merupakan hukum dasar bagi Pakistan. (3) Pembatalan semua undang-undang yang ada dan bertentangan dengan Syari'at Islam dan kemudian menangguhkan semua undang-undang yang tidak sesuai dengan Syari'at Islam. (4) Pemerintah Pakistan (harus) mempergunakan kekuasaannya sesuai dengan batas-batas yang telah ditetapkan oleh Syari'at Islam.

Begitulah, betapa hebatnya, prinsip kedaulatan Tuhan dipahami oleh sejumlah intelektual Islam sehingga menafikan demokrasi, yang berprinsip pada kedaulatan rakyat. Sekalipun demikian, di sinilah sebenarnya telah terjadi kesenjangan teoretik negara Islam, sehingga di masa modern sekarang ini konsep negara Islam sudah mengapresiasi demokrasi sebagai sistem politik ideal.

Kedaulatan Tuhan sebagai prinsip dasar negara Islam sebenarnya diambil oleh para pemikir berasal dari al-Qur'an yang menegaskan bahwa Allah-lah yang paling berdaulat dan berkuasa di seluruh alam semesta. Karena itu, kedaulatan tidak boleh diserahkan kepada rakyat. Allah berfirman: "Sesungguhnya Allah Maha Kuasa atas segala sesuatu." (QS. Al-Baqarah: 110) "Katakanlah Ya Allah yang memiliki kerajaaan, Engkau berikan kekuasaan kepada siapa saja yang dikehendaki." (QS. Ali Imran: 26-27)

Ayat ini secara tekstual menjelaskan kekuasan Tuhan kepada umat manusia, bukan dalam hubungan manusia dengan manusia dan secara kontekstual dimaknai oleh para pemikir politik Islam sebagai prinsip kedaulatan Tuhan, karena ayat di atas mengeksplorasi urusan pemerintahan di dunia, dan kekuasaan menjadi dalih adanya kedaulatan Tuhan yang diimplementasikan oleh Khalifah. Sedangkan khalifah adalah sebagai pengganti Tuhan di bumi dalam hal kekuasaan, tetapi bukan dalam urusan agama.

Pendirian negara adalah suatu keniscayaan bagi umat manusia. Dalam hal kewajiban mendirikan negara, memang konsep Islam sudah tegas menggisyaratkan, seperti tersebut di dalam hadits, "Jika kalian bertiga bepergian, maka angkatlah salah seorang di antara kamu sebagai pemimpin." Sehingga wajar jika Ibnu Khaldun, al-Mawardi, dan al-Ghazali serta sejumlah pemikir politik Islam lainnya berpandangan bahwa mendirikan negara 
adalah suatu naluri manusia yang hidup bermasyarakat. Dalam prakteknya, pendirian negara Islam dimaksudkan untuk menjamin berlakunya Syari'at Islam, seperti pelaksanaan hukum hudud/ jinayat. Karena itu, al-Qur'an lebih sering menggunakan kalimat "ahkama bainahum" yang disertai dengan kalimat "bima anzalallah," atau kalimat "litahkuma bainannas" dibarengi dengan kalimat "bima arakallah." Bahkan ditegaskan di dalam surat al-Maidah bahwa "barangsiapa yang tidak memutuskan menurut apa yang diturunkan Allah, maka mereka itu adalah orang-orang yang kafir (QS. Al-Maidah: 44), orang-orang yang zhalim (QS. Al-Maidah: 45) dan orang-orang yang fasik." (QS. Al-Maidah: 47)

Dari sinilah kemudian ditarik pengertian bahwa mendirikan negara bagi pendukung negara Islam adalah untuk menegakkan Syari'at Islam. Pendapat ini dianut oleh al-Nasafi, al-Syahrastani dan Ibnu Taimiyah bahwa kaum Muslimin berkewajiban mendirikan negara (mengangkat imam) untuk memberlakukan hukum Islam. Maka menjadi jelas, negara Islam adalah negara yang memberlakukan Syari'at Islam. Sebaliknya, negara yang tidak memberlakukan Syari'at Islam bukan disebut sebagai negara Islam.

Pandangan ini berbeda dengan kalangan yang tidak setuju dengan berdirinya negara Islam. Menurut Asghar Ali Engineer (2000), tak ada konsep baku tentang negara Islam, apalagi yang bersifat ilahiah dan kekal. Al-Qur'an hanya menjelaskan konsep tentang masyarakat, bukan tentang negara. Teori negara Islam mengalami proses perubahan dan cenderung menyesuaikan diri terhadap situasi konkret, bukannya terhadap suatu keadaan tertentu. Apa yang dilakukan Nabi Muhammad di Madinah adalah negara historis, yang senantiasa berubah sesuai dengan kebutuhan. Evolusi negara yang dimulai sejak Nabi Muhammad di Madinah sampai masa Khilafah Turki Utsmani adalah negara historis, bukan negara ideologis-teokratik yang sudah dibakukan di dalam al-Qur'an dan Sunnah. Karena itu, negara di Madinah hanyalah sekadar kebutuhan manusiawi, yang aturannya diserahkan kepada manusia.

\section{Simbiosis Agama dan Politik}


Para pemikir politik Islam (terlepas dari paradigma dan spektrum pemikiran mereka) berupaya untuk mengharmonikan antara tuntutan Syari'ah dan realitas politik. Tampaknya mereka ingin menganalisis dan membuktikan bahwa agama dan politik dalam Islam terkait secara simbiotik. Solusi yang mereka tawarkan atas masalah hubungan antara agama dan politik dapat dilihat sebagai upaya untuk memahami konsep integrasi.

Integrasi ini pada dasarnya adalah untuk menyatukan hubungan antara Tuhan, manusia dan alam, serta dalam terapan teknisnya adalah mengintegrasikan antara ilmu agama dan ilmu umum. Hal ini mengarahkan pemikiran Islam pada komitmen dan orientasi pemikiran politik Islam yang melahirkan konsep kewajiban manusia untuk membangun masyarakat ideal, yang realisasinya mensyaratkan pembentukan institusi-institusi politik yang islami.

Dari perspektif ini, integrasi mengidealkan tidak adanya pemisahan antara yang sakral dan yang profan, atau antara agama dan politik. Berbagai macam pemecahan masalah hubungan agama dan politik telah dikemukakan oleh para pemikir politik Islam di berbagai negara.

Integrasi ini menimbulkan dua agenda besar dalam pemikiran Islam pada umumnya, dan pemikiran politik Islam pada khususnya. Agenda pemikiran politik Islam berkembang menjadi dua tema besar, yaitu: pertama, hubungan antara wahyu dan akal. Kedua, hubungan antara agama dan politik. Tentu saja, kedua hal tersebut tidak dapat terpisah satu sama lain, karena keduanya berhubungan sangat erat.

Idealitas politik Islam merupakan refleksi dari hubungan agama dan politikdalam Islam, disamping pada saatyangbersamaan, sebagai kesimpulan atas wahyu melalui penggunaan akal.

\section{Karakteristik Politik Islam}

Upaya yang paling penting dalam menganalisis karakteristik pemikiran politik Islam dalam perspektif orientasi ideologis di antara gerakan-gerakan politik Islam adalah dengan kategorisasi. Upaya kategorisasi ini tidak bisa dihindarkan jika seseorang akan menganalisis suatu fenomena yang kompleks, seperti 
gerakan-gerakan Islam di seluruh dunia atau dalam suatu negeri Muslim tertentu.

Dengan upaya kategorisasi, akan dikemukakan tipetipe pemecahan yang ditawarkan para pemikir politik Islam di zaman modern atas masalah hubungan antara Islam dan politik, yang di satu sisi merefleksikan sikap "menatap keluar" (outwardlooking) dalam merespon tantangan dari Barat, dan di sisi lain, menjelma menjadi sikap "menatap ke dalam" (inward-looking) dalam mengkonstruksi pendekatan-pendekatan metodologis atas sumber-sumber pemikiran Islam: yakni Al-Qur'an, Hadits dan sumber lainnya.

Dua sikap di atas telah mendorong lahirnya tipologi pemikiran politik Islam yang juga mencerminkan pendekatanpendekatan atas Islam. Menurut William E. Sephard, tipologi yang dipertahankan dalam studi ini dapat dikatakan sebagai tipologi dari respon-respon atas pengaruh Barat dan dari metode Ijtihad. Hal ini juga berkaitan dengan metode mereka dalam memahami sumber-sumber Islam, yang dapat ditandai dengan pendekatanpendekatan 'tekstual' dan 'skriptural' (literal) di satu sisi, dan di sisi lain dengan pendekatan 'rasional' dan 'kontekstual' (liberal). Secara kategorial, paling tidak ada tiga paradigma dalam pemikiran politik Islam, ${ }^{2}$ yaitu:

Pertama, paradigma Integralistik. Paradigma ini mengajukan konsep bersatunya agama dan negara. Agama (Islam) dan negara tidak dapat dipisahkan (integrated). Islam adalah din wa dawlah. ${ }^{3}$ Apa yang merupakan wilayah agama juga otomatis merupakan wilayah politik atau negara. Negara merupakan lembaga politik dan keagamaan sekaligus. Antara keduanya merupakan totalitas utuh dan tidak dapat dipisahkan.

Secara singkat dapat dikatakan bahwa inti landasan teologis paradigma pertama ini adalah keyakinan akan watak

${ }^{2}$ Masykuri Abdillah, Demokrasi di Persimpangan Makna: Respons Intelektual Muslim Indonesia terhadap Demokrasi (1966-1993), (Yogyakarta: Tiara Wacana, 1999), h. 57.

${ }^{3}$ Lihat Muhammad Yusuf Musa, Niẓām al-Hukm fi al-Islām, (Kairo: Dār alKitāb al-'Arabỉ, 1963), h. 18. Bandingkan dengan Abdul Baqi Surur, Dawlah al-Qur`ān, (Kairo: Dār al-Nahḍah, 1972), h. 80. 
holistik Islam. ${ }^{4}$ Premis keagamaan ini dipandang sebagai petunjuk bahwa Islam menyediakan ajaran yang lengkap mengenai semua aspek kehidupan. Bahkan, sudut pandang khusus ini menjadi basis utama pemahaman bahwa Islam tidak mengakui pemisahan antara agama dan negara, antara yang transendental dan yang profan.

Pengikut paradigma integralistik yakin bahwa Islam merupakan agama yang menyeluruh, mencakup semua aspek kehidupan. Selain itu, mereka juga menekankan adanya perbedaan (distinctiveness) dan pertentangan antara Islam dan Barat, serta yakin pada kebenaran Islam yang menghadapi tantangan dari Barat. Dalam wilayah politik, mereka cenderung menghindar dari setiap ide yang dipandang terbaratkan, dan karena itu dianggap tidak Islami. Dengan pemahaman atas Islam secara literal dan tekstual, mereka lebih berupaya mengembangkan konsep-konsep mereka sendiri dari perspektif Islam sebagai alternatif atas konsepkonsep Barat.

Menurut pendekatan kaum ini, Islam diturunkan sudah dalam kelengkapan yang utuh dan bulat. Dengan ungkapan lain, Islam telah memiliki konsep-konsep lengkap untuk tiap-tiap bidang kehidupan. Pandangan ini telah mendorong pemeluknya untuk percaya bahwa Islam mencakup cara hidup yang komprehensif. Bahkan, sebagian kalangan melangkah lebih jauh dari itu; mereka menekankan bahwa Islam adalah sebuah totalitas yang padu yang menawarkan pemecahan terhadap semua masalah kehidupan.

Dalam perspektif ini, beberapa kalangan Muslim beranggapan bahwa Islam harus menjadi dasar negara; bahwa syari'ah Islam harus diterima sebagai konstitusi negara; bahwa kedaulatan politik ada di tangan Tuhan; bahwa gagasan tentang negara bangsa (nation-state) bertentangan dengan konsep ummah (komunitas Islam) yang tidak mengenal batas-batas politik dan teritorial. ${ }^{5}$ Singkatnya, model yang pertama ini merefleksikan adanya kecenderungan untuk menekankan aspek-aspek legal-

${ }^{4}$ Ada banyak ayat al-Qur`an yang dapat digunakan untuk mendukung pernyataan ini. Ayat yang paling sering dirujuk adalah al-Qur`an 16:89 yang berbunyi: "Dan Kami turunkan kepadamu kitab suci untuk menjelaskan segala sesuatu, dan petunjuk serta rahmat dan kabar gembira bagi mereka yang berserah diri (kepada Allah)".

${ }^{5}$ Qamaruddin Khan, Pemikiran Politik Ibnu Taymiyah, (Bandung: Pustaka, 1995), h. 172. 
formal idealisme Islam. Konsekuensi dari paradigma ini adalah sistem politik modern diletakkan dalam posisi vis a vis dengan ajaran-ajaran Islam.

Pengikut paradigma ini ingin melakukan reformasi sistem sosial dengan kembali kepada ajaran Islam dan tradisi Nabi secara total dan menolak sistem yang dibuat manusia. Para penganut paradigma ini adalah Khurshid Ahmad, ${ }^{6}$ Muhammad Asad, ${ }^{7}$ Muhammad Husayn Fadhlallah, ${ }^{8}$ Sayyid Quthb (1906-1966), ${ }^{9}$ Abu alA'la al-Mawdudi (1903-1979), ${ }^{10}$ dan Hasan Turabi. ${ }^{11}$

Abu al-A'la Mawdudi misalnya, mengatakan bahwa Islam bukanlah campuran dari ide-ideyang tidak saling terkait dan bentukbentuk perilaku yang berubah. Ia merupakan sistem yang teratur, universalitas yang tetap, bersandar pada seperangkat postulat yang jelas dan pasti. Lebih lanjut ia mengatakan, "Syari'ah ini merupakan skema lengkap dari kehidupan dan tatanan sosial yang saling

${ }^{6}$ Lihat, Ahmad Khurshid, "Islam: Basic Principles and Characterristics", dalam Islam: Its Meaning and Message, (Leicester: Islamic Foundation, 1976).

${ }^{7}$ Bagi Asad, yang sebelum memeluk Islam bernama Leopold Weiss, suatu negara dapat menjadi benar-benar Islami hanyalah dengan keharusan pelaksanaan yang sadar dari ajaran Islam terhadap kehidupan bangsa dan dengan jalan menyatukan ajaran itu ke dalam undang-undang negara. Negara, tandas Asad, merupakan syarat mutlak bagi kehidupan Islam. Dan ia menolak dengan keras bentuk negara sekuler. Pemikiran politiknya dapat dibaca dalam Muhammad Asad, The Principles of State and Government in Islam, (Gibraltar: Dār al-Andalus, 1980).

${ }^{8}$ Lihat dalam Muhammad Husayn Fadhlallah, Al-Islām wa Manthiq alQuwwah, (Beirut: al-Idārah al-Islāmiyah, 1986); al-Ḥarakah al-Islāmiyyah: Humūm wa Naqdiyah, (Beirut: Dar al-Malak, 1990).

9 Pemikiran-pemikiran Sayyid Qutb dapat dibaca dalam Al-Adālah alIjtimā’iyah fī al-Islām, (Beirut: Dar al-Kitab al-'Arabiy, 1967).

${ }^{10}$ Untuk mengetahui pemikiran politiknya, baca antara lain karya-karya [1] Abu al-A'lā al-Mawdūdi, Al-Mabādi` al-Asāsiyah li al-Dawlah al-Islāmiyah, (Jeddah: Dār as-Sa'udiyah li an-Nasyr wa at-Tawzi', Tanpa Tahun); [2] Nadhariyyat al-Islām al-Siyâsiyah, (Jeddah: Dār as-Sa'udiyah li an-Nasyr wa at-Tawzi', t.th); [3] Political Theory of Islam (Lahore: Islamic Publications, 1976).

${ }^{11}$ Secara lebih lengkap dan utuh, pemikirannya dapat dibaca, antara lain, dalam Hasan Turabi, [1] “The Islamic State” dalam dalam Voices of Resurgent Islam, disunting oleh John L. Esposito, (New York: Oxford University Press, 1983); [2] "Islam, Democracy, the State, and the West”, Middle East Policy 1, No. 3, 1992; [3] al-H arākah al-Islāmiyah fi Sudan: at-Tathawwur wa al-Kasb wa al-Manhaj, (Lahore: Iman, 1410/1990); [3] Al-Șahwah al-Islāmiyah wa al-Dawlah al-Quthriyyah fi al-Wathan al-'Arabiy, dalam Sa'd ad-Dīn Ibrahim (ed.), al-Ṣaḥwah al-Islāmiyah wa Humūm alWathan al-'Arabiy, (Amman: Muntadza al-Fikr al-'Arabiy, 1988). 
melengkapi; tidak kurang dan tidak lebih." ${ }^{12}$ Pernyataan ini jelas mengungkapkan posisi Maududi dalam konseptualisasinya tentang negara Islam. Baginya, syari'ah tidak mengakui adanya pemisahan antara agama dan politik, atau antara agama dan negara.

Kedua, Paradigma Substantif. Pengikut paradigma ini mengajukan pandangan bahwa agama dan negara berhubungan secara mutualistik, yaitu berhubungan timbal balik dan saling membutuhkan-menguntungkan. Dalam kaitan ini, agama membutuhkan negara. Sebab, melalui negara, agama dapat berbiak dengan baik. Hukum-hukum agama juga dapat ditegakkan melalui kekuasaan negara. Begitu juga sebaliknya, negara memerlukan kehadiran agama, karena hanya dengan agama suatu negara dapat berjalan dalam sinaran etik-moral.

Paradigma ini juga memandang bahwa Islam tidak meletakkan suatu pola baku tentang teori negara yang harus dijalankan oleh ummah. ${ }^{13}$ Meskipun terdapat berbagai ungkapan dalam al-Qur`an yang seolah-olah merujuk pada kekuasaan politik dan otoritas, ungkapan-ungkapan ini hanya bersifat insidental dan tidak ada pengaruhnya bagi teori politik. Bagi mereka, jelas bahwa al-Qur`an bukanlah buku tentang ilmu politik. Menurut aliran pemikiran ini, istilah dawlah yang berarti negara tidak dijumpai dalam al-Qur`an. Istilah dawlah memang ada, tapi bukan bermakna negara. Istilah ini dipakai secara figuratif untuk melukiskan peredaran atau pergantian tangan dari kekayaan. Hanya dalam perjalanan waktu, makna harfiyah ini telah berkembang untuk menyatakan kekuasaan politik karena kekuasaan itu selalu berpindah tangan.

Walaupun demikian, penting untuk dicatat bahwa mereka mengakui bahwa al-Qur`an mengandung nilai-nilai dan ajaran-ajaran yang bersifat etis yang kemudian menjadi landasan bagi aktivitas sosial dan politik umat manusia. Ajaran-ajaran ini

${ }^{12}$ Abu al-A'lā al-Mawdūdi, "Political Theory of Islam", dalam bukunya Islamic Law and Constitution, disunting oleh Khurshid Ahmad, (Lahore: tp, 1967), h. 133.

${ }^{13}$ Ahmad Syafi'i Ma'arif, Islam as the Basis of State: A Study of the Islamic Political Ideas as Reflekcted in the Constituent Assembly Debates in Indonesia, disertasi doktor, University of Chicago, 1983, h. 23. Bandingkan dengan Bahtiar Effendi, Islam dan Negara, h. 13. 
mencakup prinsip-prinsip keadilan (al-'adâlah), kesamaan (almusâwah), persaudaraan (al-ukhuwwah) dan kebebasan (al-hurriyah). Untuk itu, bagi kalangan yang berpendapat demikian, sepanjang negara berpegang pada prinsip-prinsip seperti itu, maka mekanisme yang diterapkannya adalah sesuai dengan ajaran Islam (islâmy).

Para pendukung pemikiran ini, di antaranya adalah Mohamad Husayn Haykal (1888-1956), ${ }^{14}$ Muhammad Abduh (1849-1905), Fazlurrahman (1919-1988), ${ }^{15}$ dan Qamaruddin Khan. ${ }^{16}$ Menurut mereka, pembentukan sebuah negara Islam dalam pengertiannya yang formal dan ideologis tidaklah begitu penting. Sebagai kebalikan aliran dan model paradigma tradisionalis, maka paradigma modernis menekankan substansi daripada bentuk negara yang legal-formal. Bagi pendapat ini, yang pokok adalah negara -karena posisinya yang bisa menjadi instrumen dalam merealisasikan ajaran-ajaran agama- dapat menjamin tumbuhnya nilai-nilai dasar seperti itu. ${ }^{17}$

Ketiga, Paradigma Sekularistik. Paradigma ini menolak kedua paradigma sebelumnya; integralistik dan substantif. Sebagai gantinya, diajukanlah konsep pemisahan antara agama dan negara. Dalam konteks Islam, paradigma sekularistik menolak pendasaran negara pada Islam, atau menolak determinasi Islam pada bentuk tertentu dari negara. Agama bukanlah dasar negara, tetapi agama lebih bersifat sebagai persoalan individual semata. Dengan

${ }^{14}$ Pemikiran politik Husayn Haikal dapat dibaca dalam karya-karya, antara lain; al-Ḥukūmah al-Islāmiyah, (Kairo: Dār al-Ma’arif, 1993); Mudzakkirāt fi asSiyāsah al-Mishriyah, (Kairo: Dar al-Ma’arif, 1990).

${ }^{15}$ Tentang pemikiran politiknya, dapat dibaca dalam Fazlurrahman, The Islamic Concept of State, dalam John J. Donohue dan L. Esposito (ed.), Islam in Transition: Muslim Perspective, (New York: Oxford University Press, 1982); Islam, (Jakarta: Bina Aksara, 1987).

${ }^{16}$ Qamaruddin Khan mengatakan, klaim bahwa Islam merupakan sebuah panduan agama dan politik yang harmonis adalah sebuah slogan modern, yang jejaknya tidak dapat ditemukan dalam sejarah masa lalu Islam. Istilah "negara Islam" tidak pernah digunakan di dalam teori atau praktik ilmu politik Muslim, sebelum abad kedua puluh. Juga, seandainya tiga puluh tahun pertama Islam dikecualikan, perilaku negara-negara Muslim di dalam sejarah hampir tidak dapat dibedakan dari perilaku negara-negara lainnya dalam sejarah dunia”. Tentang pemikiran politiknya, dapat dibaca dalam Qamaruddin Khan, Teori Politik Islam, (Bandung: Pustaka, 1998).

${ }^{17}$ Bahtiar Effendi, Islam dan..., h. 14. 
perkataan lain, aliran ini berpendirian bahwa Islam adalah agama dalam pengertian Barat yang tidak bertali temali dengan urusan kenegaraan. Para pemikir politik yang masuk dalam kategori paradigma ketiga adalah Ali Abdurraziq (1888-1966), Thaha Husein (1889-1973), ${ }^{18}$ Ahmad Luthfi Sayyid (1872-1963), ${ }^{19}$ kemudian disusul belakangan oleh Muhammad Sa'id al-Asymawi (Mesir, lahir 1932).

\section{E. Mainstream Politik Islam di Indonesia}

Kategorisasi pemikiran politik Islam di atas berpengaruh terhadap mainstream politik Islam di Indonesia. Pada dasarnya mainstream ini masih berirama dengan tiga paradigma pemikiran politik di atas, walaupun di Indonesia juga terlihat kekhasan karena setting kultural dan sosial-politik tertentu. Sejauh berkaitan dengan masalah orientasi politik, setidaknya ada tiga mainstream ${ }^{20}$ dalam peta politik di Indonesia:

Pertama, Arus Formalistik. Terminologi ini dimaksudkan untuk mengacu pada bentuk pemikiran mereka yang mempertahankan pelaksanaan secara ketat dari bentuk-bentuk Islam yang formal. Dalam konteks politik, pengikut arus ini menunjukkan orientasi yang cenderung mempertahankan bentukbentuk pra-konsepsi politik Islam, seperti pentingnya partai politik Islam yang formal; menggunakan nama Islam, memakai ungkapan

${ }^{18}$ Di antara gagasan Thaha Husein adalah [a] kejaan dan kemakmuran dunia Islam dapat terwujud kembali bukan dengan jalan kembali kepada ajaran Islam yang lama, dan juga bukan dengan mengadakan reformasi atau pembaharuan ajaran Islam, tetapi dengan perubahan-perubahan total yang berwatak liberal dan sekular dengan mengacu kepada Barat; [b] dari awal sejarahnya, Islam dan negara memang selalu terpisah. "Umat Islam sadar terhadap suatu prinsip yang sekarang ini telah diakui secara universal bahwa sistem politik dan agama itu dua hal yang terpisah, dan bahwa negara itu didasarkan atas landasan-landasan praktis. Lihat Munawir Sadzali, Islam dan Tata Negara:Ajaran, Sejarah dan Pemikiran, (Jakarta: UI-Press, 1990), h. 139. Lihat, Thaha Husein, al-Fitnah al-Kubra, dalam al-Majmu'ah al-Kāmilah li Mu`allafāt al-Duktur Thahā Husein, (Beirut: Dar al-Kitab al-Lubnani, 1973), Juz IV, h. 227 dan 218.

${ }^{19}$ Luthfi Sayyid lebih menekankan identitas nasional Mesir daripada Islam, dan pemisahan antara agama dan politik, serta perlunya Mesir meniru secara selektif pola politik, ekonomi, dan sosial Barat. Menurutnya, baik Pan-Islamisme maupun Pan-Arabisme tidak lagi relevan dengan realitas dunia Islam pada zaman modern ini, yang pada kenyataannya telah terbagi dalam banyak wilayah dan kebangsaan. Lihat Munawir Sadzali, Islam dan..., hal. 138.

${ }^{20} \mathrm{Ibid}$, hal. 152-161. 
idiom-idiom dan simbol-simbol politik Islam, terutama konstitusi dan dasar negara Islam.

Gerakan formalis Islam dalam panggung politik Indonesia dapat dilihat pada kelompok Islam yang vokal menyerukan dihidupkannya kembali Piagam Jakarta. Kelompokini merasa bahwa Piagam Jakarta sah secara formal untuk dijadikan landasan negara Indonesia karena umat Islam adalah umat yang mayoritas. Selain itu, arus formalistik juga dapat dicermati dalam orientasi politik para aktivis partai dari kalangan umat Islam, yang secara historis telah meyakini bahwa partai politik dengan nama Islam sebagai satu-satunya sarana yang mungkin bagi artikulasi kepentingan politik orang-orang Islam.

Politisasi, menurut pengikut arus ini harus memunculkan simbolisme Islam. Hal ini tampak dengan kecenderungan penggunaan kata-kata Arab secara tegas yang secara hermeneutik dipandang Islami, misalnya statuta partai, sebagaimana yang terdapat dalam Partai Persatuan Pembangunan (PPP). Pengikut arus formalistik menurut Fachry Ali dan Bahtiar Effendy adalah Jalaluddin Rahmat dan AM. Saifuddin.

Kedua, Arus Substantivistik. Mainstream pemikiran mereka menekankan pentingnya substansi dan menolak bentuk-bentuk pemikiran formalistik. Orientasi politik mereka juga menekankan tuntutan manifestasi substansial nilai-nilai Islam dalam aktifitas politik, bukan sekedar manifestasinya secara formal; baik dalam ide-ide maupun kelembagaannya. Bagi pengikut arus ini, yang lebih penting adalah eksistensi intrinsik ajaran-ajaran Islam dalam arena politik Indonesia, dan untuk mendorong Islamisasi perlu dilakukan kulturalisasi, yaitu penyiapan budaya Islam.

Pendukung arus politik ini adalah Nurcholish Madjid dan Abdurrahman Wahid. Slogan Nurcholish Madjid "Islam yes, partai Islam no" dan pandangannya tentang Islam sebagai komplementer sebenarnya hanyalah sebagai awal dari pemikirannya dan catatan kesimpulan dari renungannya atas Islam dan historisitas umat Islam di Indonesia. Ia menemukan bahwa sebagai agama fitrah yang menekankan potensi-potensi yang inheren dalam diri manusia dalam kebebasan dan kebaikan, Islam adalah agama universal yang 
mengajarkan cita-cita kemanusiaan universal, yang mengajarkan inklusivisme, bukan eksklusivoisme. ${ }^{21}$

Pandangan senada disampaikan oleh Abdurrahman Wahid, tokoh NU yang sejak awal tahun 1980-an terkenal dengan gagasannya tentang "pribumisasi Islam” dalam menghadapi kultur Indonesia. Ide ini didasarkan pada postulat pluralisme masyarakat Indonesia, di mana Islam hanya berfungsi sebagai salah satu faktor komplementerbagibangsa Indonesia secara keseluruhan. ${ }^{22}$ Argumen sosio-historis Abdurrahman Wahid, berdampak pada deideologisasi Islam, yang tampak senada dengan kecenderungan sekularistik Ali Abdurraziq. Dalam konteks Indonesia, ide ini telah memunculkan suatu dinamika dialektis dalam memecahkan masalah konseptual menyangkut hubungan antara wawasan keislaman dan wawasan keindonesiaan.

Ketiga,ArusFundamentalis.Selain darimainstreamformalistik dan substansialistik, terdapat mainstream ketiga yang bertentangan secara diametral. Mainsteam ini cenderung mengangkat kembali sendi-sendi Islam ke dalam ranah politik modern. Mainstream ini, yang disebut "fundamentalis", pada titik pangkalnya berkeyakinan bahwa kedua arus yang lain telah gagal menunjukkan Islam sebagai penetrasi dalam merespon sistem politik modern.

Mereka memandang bahwa revolusi sebagai pembenaran atas optimisme masa depan. Banyak dari kelompok-kelompok ini ditransformasikan ke dalam kelompok sparatis, yang melalui sikap reaksioner dalam berpolitik, menantang penguasa, dan beberapa di antara mereka juga menantang kemapanan Islam dengan menawarkan semacam alternatif. ${ }^{23}$ Gerakan ini banyak dipengaruhi oleh ide-ide pemikir fundamentalis seperti Hasan alBanna dan al-Maududi, dua pemikir pemikiryang mempertahankan totalitas ajaran Islam, dan karena itu perjuangan Islam berangkat dari kerangka universalitas Islam, dan harus dijalankan dalam kehidupan sehari-hari.

${ }^{21}$ Nurcholish Madjid, Cita-cita Politik Kita, dalam Bosco Carvallo dan Dasrizal (ed.), Aspirasi Umat Islam Indonesia, (Jakarta, 1983), h. 6-7.

${ }^{22}$ Fachry Ali dan Bahtiar Effendi, Merambah Jalan Baru Islam, (Bandung: Mizan, 1986, h. 191-192.

${ }^{23}$ M. Din Syamsuddin, Islam dan..., h. 160-161. 


\section{F. Penutup}

Karakteristik pemikiran politik Islam, yang secara esensial berhubungan dengan watak dari bentuk pemerintahan dalam Islam dan rekonsiliasi antara idealitas keagamaan dan realitas politik, telah menjadi masalah utama dalam pemikiran politik Islam dan telah menimbulkan berbagai macam solusi. Solusisolusi ini berpangkal, utamanya dari penafsiran atas sumbersumber Islam al-Qur'an dan sunnah. Masalah ini, dan bagaimana kedua sumber tersebut diinterpretasikan oleh para pemikir politik Islam, keragaman kondisi politik dan budaya yang dihadapi oleh para pemikir tersebut juga mempengaruhi watak dari pemecahan masalah dan ekspresi dari pemikiran-pemikiran tersebut.

Karena para pemikir politik Islam berangkat dari keyakinan yang sama tentang keagamaan, yaitu Islam, dan mereka concern pada masalah yang sama, yaitu bagaimana mensenyawakan nilainilai Islam ke dalam realitas politik, maka mereka menempatkan Syari'ah sebagai basis moral dan politik untuk masalah-masalah politik Islam. Tetapi persepsi mereka terhadap Syari'ah dan bagaimana nilai-nilai Syari'ah tersebut diimplementasikan dalam kehidupan politik telah memunculkan keragaman pendapat.

Keragaman pendapat ini menunjukkan bahwa tradisi pemikiran politik Islam itu kaya, beraneka ragam, dan lentur. Dilihat dari perspektif ini, dalam tulisannya, "Islam and Political Development”, Michael Hudson mengemukakan bahwa sebenarnya pertanyaan yang patut dikemukakan bukanlah yang kaku dan salah arah karena bergaya mendikhotomi, yakni 'apakah Islam dan pembangunan politik itu bertentangan atau tidak,' melainkan 'seberapa banyak pemikiran Islam dan bagaimana yang sesuai dengan sistem politik modern?’ [.] 


\section{Daftar Pustaka}

Abdillah, Masykuri, Demokrasi di Persimpangan Makna Respons Intelektual Muslim Indonesia terhadap Konsep Demokrasi (19661993), Yogyakarta: Tiara Wacana, 1999.

Ali, Fahry dan Bahtiar Effendi, Merambah Jalan Baru Islam, Mizan, Bandung, 1986.

Anwar, M. Syafi'i, Pemikiran dan Aksi Islam Indonesia, Sebuah Kajian Politik Tentang Cendekiawan Muslim Orde Baru, Jakarta: Paramadina, 1995.

Azra, Azyumardi, Pergolakan Politik Islam dari Fundamentalisme, Modernisme hingga Post-Modernisme, Jakarta: Paramadina, 1996.

Basyaib, Hamid dan Hamid Abidin (Ed), Mengapa Partai Kalah, Perjalanan Politik Islam dari Pra-Pemilu '99 sampai Pemilihan Presiden, Jakarta: Alvabet, 1999.

Al-Chaidar, Pemilu 1999, Pertarungan Ideologis Partai-Islam partai Islam Versus Partai-partai Sekuler, Jakarta: Darul Falah, 1999.

Effendy, Bahtiar, Islam dan Negara, Transformasi Pemikiran dan Praktik Politik Islam di Indonesia, Jakarta: Paramadina, 1998.

Eickelman, Dale F. dan James Piscatori, Iekspresi Politik Muslim, Bandung, Mizan, 1998.

Esposito, John L. (Ed), Identitas Islam pada Perubahan Sosial-Politik, Jakarta: Bulan Bintang, 1986.

_-, Islam dan Politik, Jakarta: Bulan Bintang, 1990.

Abu Faris, Muhammad Abdul Qadir, an-Nizham as-Siyasi fi al-Islam, Lebanon: al-Ittihad al-Islami al-Alami, 1984.

Hamid, Tijani Abdul Qadir, Ushul al-Fikr as-Siyasi fi al-Qur'an al-Makki, Lebanon, al-Ittihad al-Islami al-Alami, 1995.

Huwaydi, Fahmi, Demokrasi, Oposisi dan Masyarakat Madani, Isu-isu Besar Politik Islam, Bandung: Mizan, 1996.

Imarah, Muhammad, al-Islam wa as-Siyasah ar-Radd ala Syubhat alIlmaniyun,Dar al-Tauzi' wa al-Nasyr al-Islami, 1993.

Kuntowijoyo, Identitas Politik Umat Islam, Bandung: Mizan, 1997. 
Madjid, Nurcholish, Cita-cita Politik Islam Era Reformasi, Jakarta, Paramadina, 1999.

Al-Mawdudi, Abu al-A'la, "Political Theory of Islam", dalam bukunya Islamic Law and Constitution, disunting oleh Khurshid Ahmad, Lahore, 1967.

Mustofa(ed), Memilih PartaiMendambakan Presiden BelajarBerdemokrasi di Ufuk Milenium, Jakarta: Rosdakarya, 1999.

Nashr, Sayyid Hossen, Traditional Islam in Modern World, London and New York, 1987.

Qasim, Muhyi al-Din Muhammad, as-Siyasah asy-Syari'ah wa mafhum as-Siyasah al-Hadits, Kairo: al-Ma'had al-Alamili al-Fikr alIslami, 1997.

Ridha, Muhammad Rasyid, Al-Khilâfah wa Al-Imâmah Al-Uzhma, Cairo, 1023.

Salim, Arskal, Partai Islam dan Relasi Agama-Negara, Jakarta: Puslit IAIN Jakarta, 1999.

Santoso, Agus Edi (Peny), Tidak Ada Negara Islam, Surat-surat Politik Nurcholish Madjid-Mohamad Roem, Jakarta: Djambatan, 1997. 
Abdurrahman Kasdi 